\title{
« L'esplorazione geografica dell'Iran in epoca ellenistica e romana: il contributo della documentazione archeologica ». OCNUS, 7, 1999 [2000], pp. 31-43.
}

\section{Rémy Boucharlat}

\section{(2) OpenEdition}

\section{Journals}

Édition électronique

URL : http://journals.openedition.org/abstractairanica/35302

DOI : 10.4000/abstractairanica.35302

ISSN : 1961-960X

Éditeur :

CNRS (UMR 7528 Mondes iraniens et indiens), Éditions de l'IFRI

Édition imprimée

Date de publication : 15 mai 2002

ISSN : 0240-8910

\section{Référence électronique}

Rémy Boucharlat, « « L'esplorazione geografica dell'Iran in epoca ellenistica e romana: il contributo della documentazione archeologica ». OCNUS, 7, 1999 [2000], pp. 31-43. », Abstracta Iranica [En ligne], Volume 23 | 2002, document 92, mis en ligne le 08 février 2010, consulté le 25 septembre 2020. URL http://journals.openedition.org/abstractairanica/35302 ; DOI : https://doi.org/10.4000/ abstractairanica.35302

Ce document a été généré automatiquement le 25 septembre 2020.

Tous droits réservés 


\section{« L'esplorazione geografica dell'Iran in epoca ellenistica e romana: il contributo della documentazione archeologica ». OCNUS, 7, 1999 [2000], pp. 31-43.}

\section{Rémy Boucharlat}

À partir des sources écrites, que confirment, de façon ponctuelle seulement, les données archéologiques dans le Caucase et le long des fleuves Uzboj et Amou daria en Asie centrale, l'A. montre bien la différence d'objectifs des Gréco-Macédoniens et des Romains dans leur approche du monde iranien; pour les premiers, les explorations dans le nord avaient un but politique dans un monde qu'ils tenaient en partie ; pour les seconds, qui rapidement acceptent la frontière orientale de leur empire en Mésopotamie, il s'agit de contourner le Plateau iranien par le nord (et par le sud, via la Mer Rouge et l'Océan indien) pour tenter d'établir des liens vers la Bactriane, le Gandhara et l'Inde. Des objets ont circulé, mais l'existence d'une route proprement dite reste à prouver.

\section{INDEX}

Thèmes : 3.2.3. Séleucides, Parthes et Sassanides 
AUTEURS

RÉMY BOUCHARLAT

CNRS - Lyon 